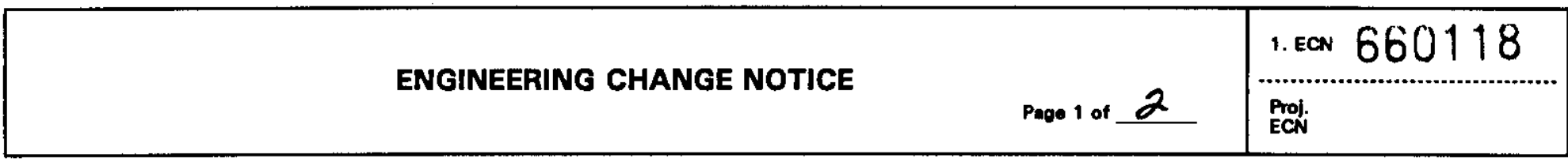

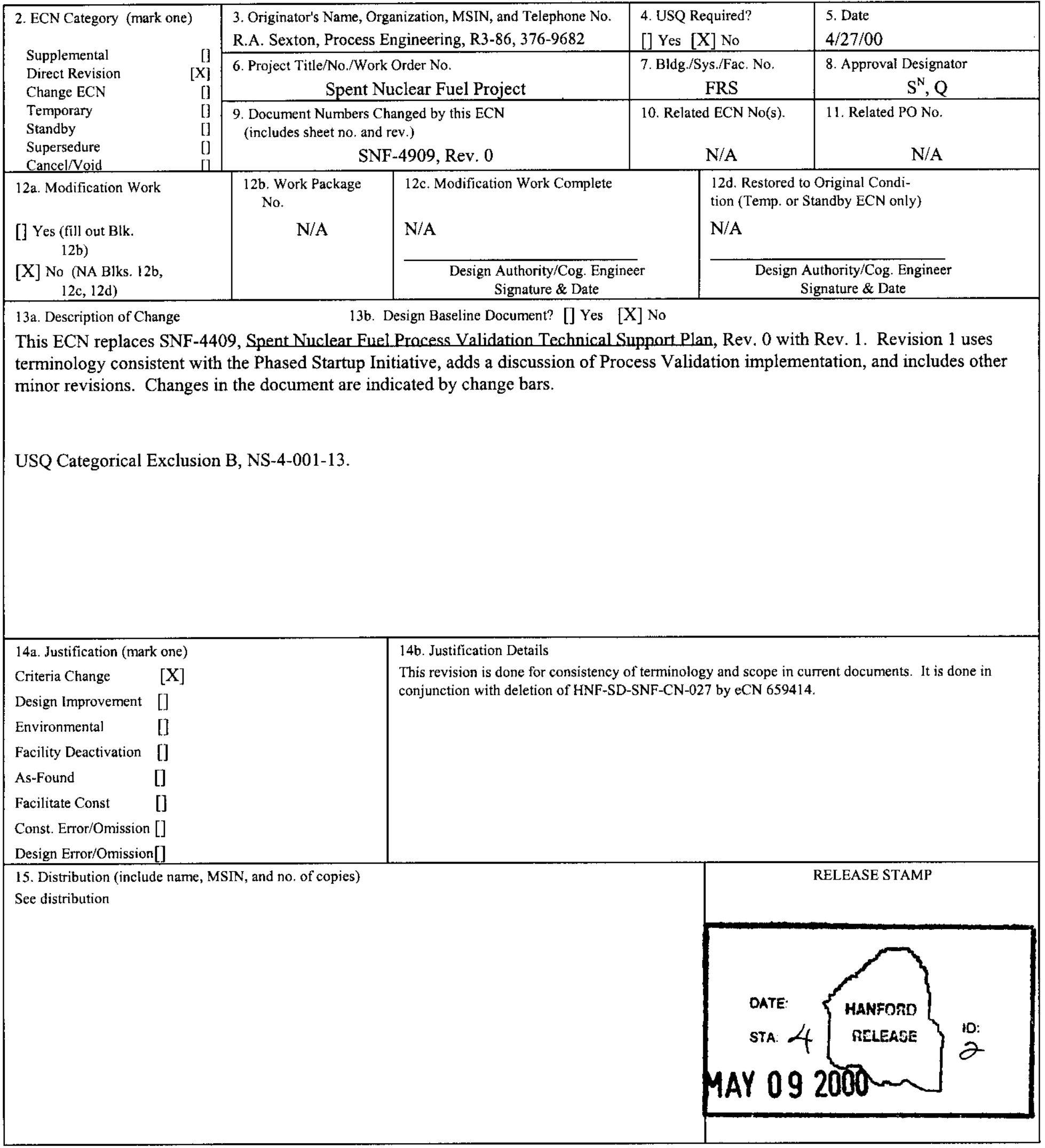




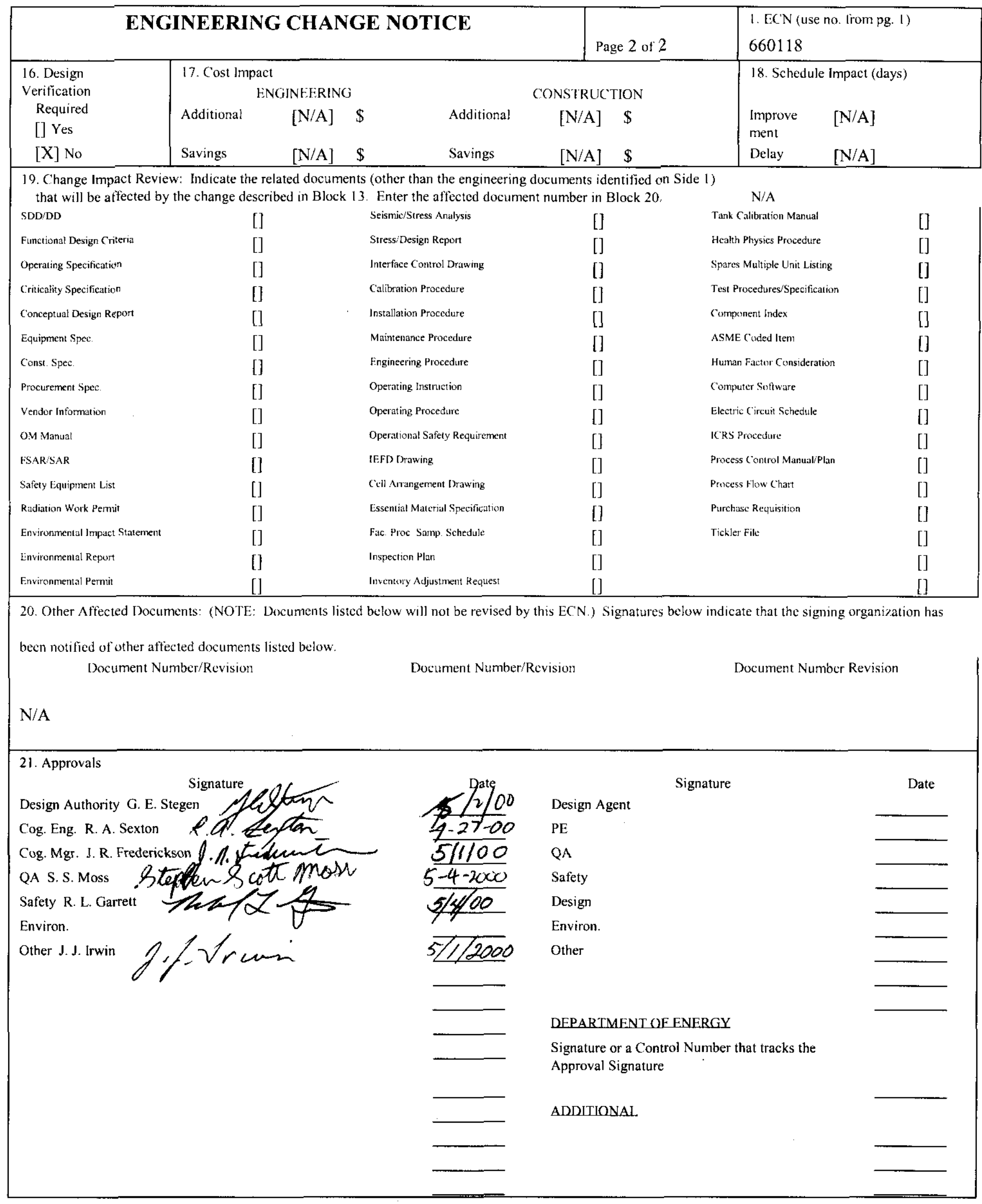


SNF-4909

Revision 1

\section{Spent Nuclear Fuel Process Validation Technical Support Plan}

Prepared for the U.S. Department of Energy

Assistant Secretary for Environmental Management

Project Hanford Management Contractor for the

U.S. Department of Energy under Contract DE-AC06-96RL13200

Fluor Hanford

P.O. Box 1000

Richland, Washington 


\section{TRADEMARK DISCLAIMER}

Reference herein to any specific commercial product, process,

or service by trade name, trademark, manufacturer, or

otherwise, does not necessarily constitute or imply its

endorsement, recommendation, or favoring by the United

States Government or any agency thereof or its contractors or subcontractors.

This report has been reproduced from the best available copy. Available in paper copy and microfiche.

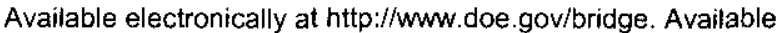
for a processing fee to the U.S. Department of Energy and its contractors, in paper, from:

U.S. Department of Energy

Office of Scientific and Technical Information

P.O. Box 62

Oak Ridge, TN 37831-0062

phone: $865-576-8401$

fax: 865-576-5728

email: reports@adonis.osti.gov(423) 576-8401

Printed in the United States of America

Total Pages: $\quad 36$ 


\title{
Spent Nuclear Fuel Process Validation Technical Support Plan
}

\author{
R. A. Sexton
}

Technical Resources International, Inc.

Date Published

May 2000

Prepared for the U.S. Department of Energy

Assistant Secretary for Environmental Management

Project Hanford Management Contractor for the

U.S. Department of Energy under Contract DE-AC06-96RL13200

\section{Fluor Hanford}

P.O. Box 1000

Richland, Washington

34 - Jotal pages.
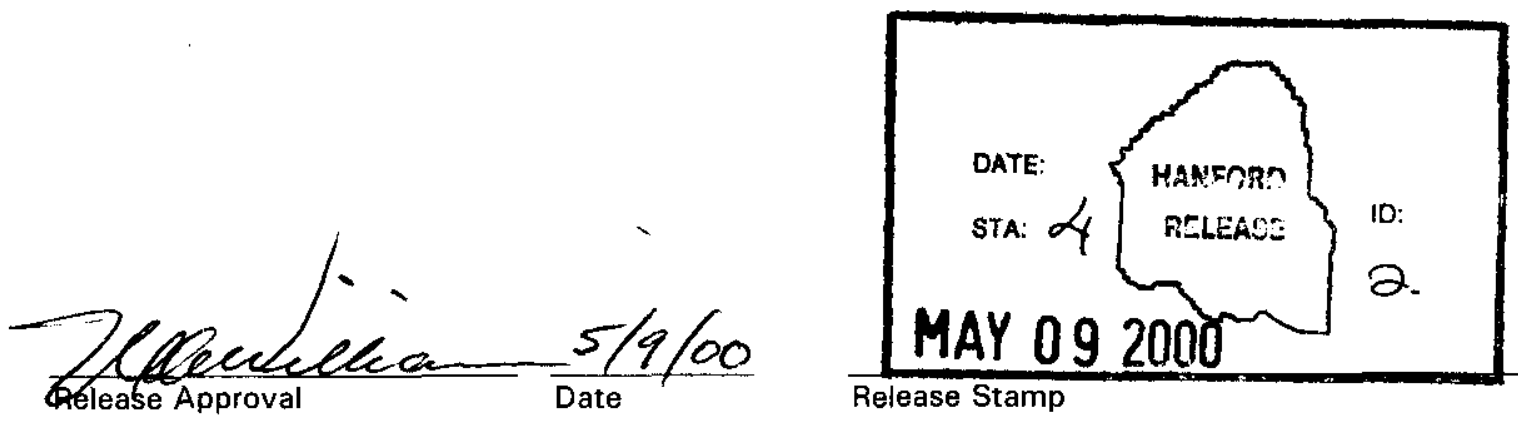


\section{RECORD OF REVISION}

(1) Document Number

SNF-4909, Rev. 1

Page 1

(2) Title

Spent Nuclear Fuel Process Validation Technical Support Plan

CHANGE CONTROL RECORD

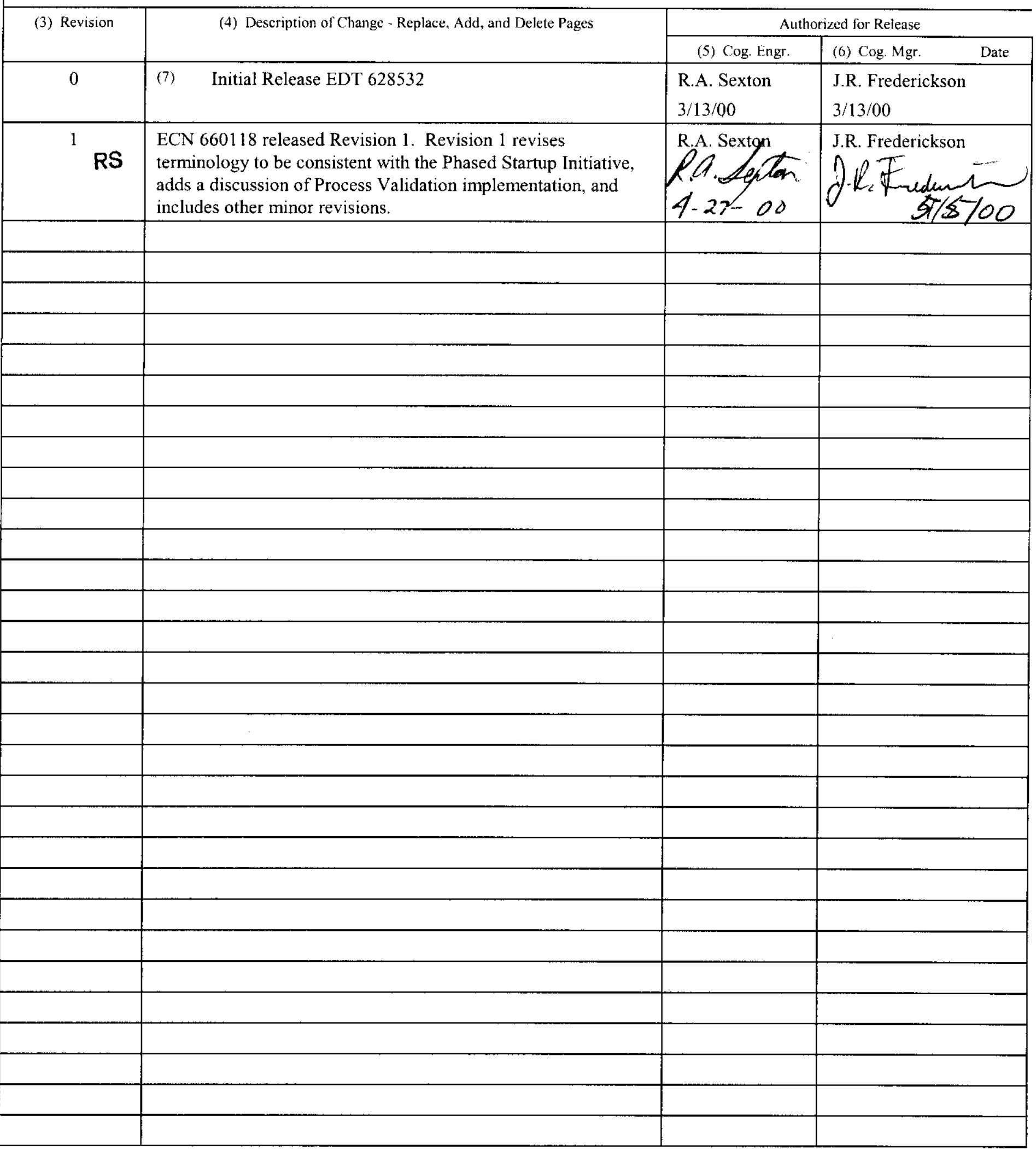


PROCESS VALIDATION TECHNICAL SUPPORT PLAN

\section{TABLE OF CONTENTS}

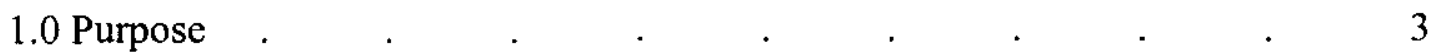

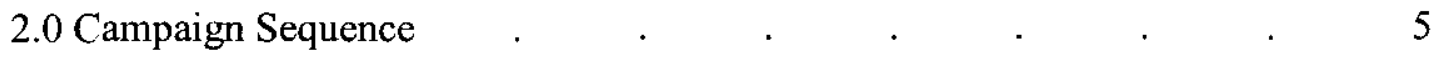

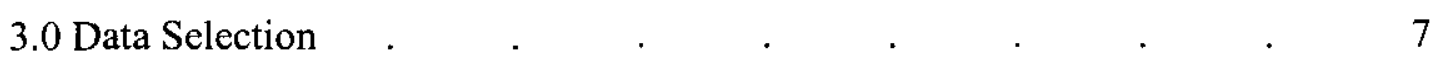

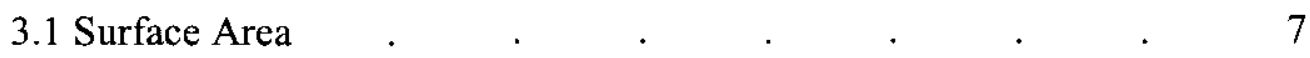

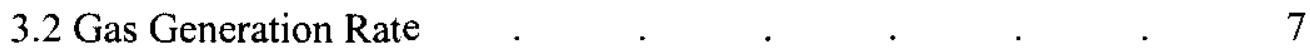

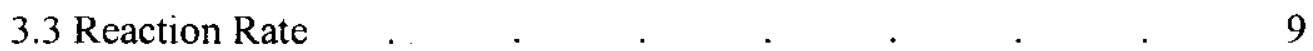

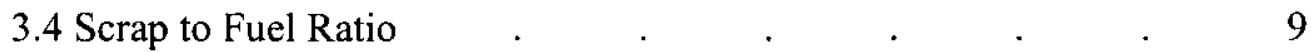

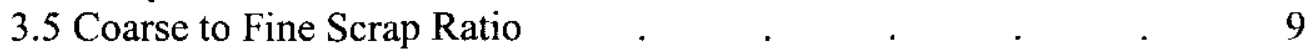

3.6 Particulate. $\quad . \quad$. $\quad . \quad$. $\quad . \quad$. $\quad$. 9

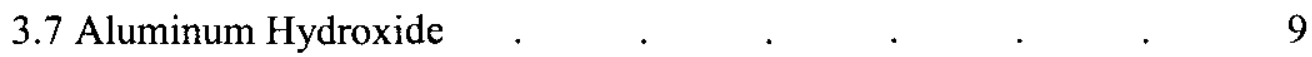

3.8 Radiological . . . . . . . . . . $\quad .10$

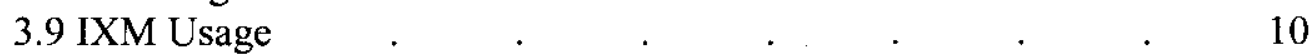

3.10 Sludge Treatment Feed . $\quad . \quad$. $\quad$. $\quad$. $\quad$. 10

3.11 Uranium Mass in Knockout Pot . $\quad . \quad$. $\quad . \quad$. 10

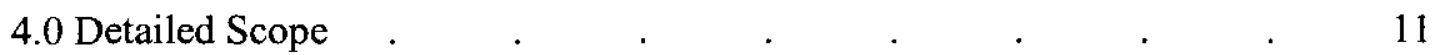

4.1 Delidding . $\quad . \quad$. $\quad . \quad$. $\quad . \quad$. $\quad . \quad 11$

4.1.1 Visual Examination Prior to Cleaning . . . $\quad 11$

4.1.2 Weigh Fuel Prior to Cleaning . . . . . 11

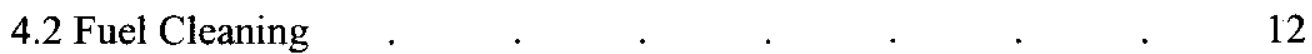

4.2.1 Measure Radiation of Effluent During Cleaning
and Decapping

4.2.2 Weigh Canister After Cleaning . $\quad$. $\quad$. 12

4.2.3 Visual Examination of Fuel After Cleaning . . $\quad 13$

4.2.4 Visually Inspect Canister After Dumping . . $\quad 13$

4.2.5 Weigh Canister After Dumping. . . . 14

4.2.6 Visually Quantify Sludge Released by Disassembly
After Cleaning

4.2.7 Visually Inspect Coarse Scrap . $\quad$. $\quad$. $\quad$. 14

4.2.8 Weigh and Measure Volume of Coarse Scrap .. $\quad$. $\quad 15$

4.2.9 Visually Inspect Fine Scrap . . . . . $\quad 15$

4.2.10 Weigh and Measure Volume of Fine Scrap . $\quad 16$

4.2.11 Visually Inspect Fine Scrap in Cleaning Machine Screen $\quad 16$

4.2.12 Weigh Fine Scrap in Cleaning Machine Screen . 17

$\begin{array}{lll}\text { 4.2.13 Observe Gas Bubbles From Scrap Canisters After } & \\ \text { Cleaning . . . } & 17\end{array}$

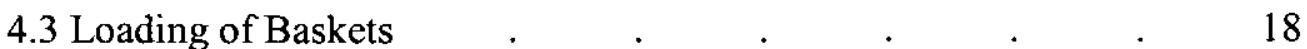

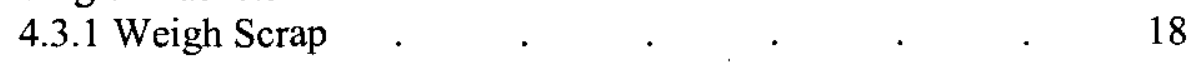

4.3.2 Weigh Coarse and Fine Scrap . . . . $\quad$. $\quad 19$ 
TABLE OF CONTENTS (cont.)

4.3.3 Visual Examination of Loaded Fuel and Scrap Baskets $\quad 19$

4.3.4 Observe Gas Bubbles From Loaded Baskets . . . 20

4.4 Loading of $\mathrm{MCO}$. $\quad$. $\quad$. $\quad$. $\quad$. $\quad$. $\quad 20$

4.4.1 Measure Centerline Temperature of Loaded MCO . $\quad 20$

4.4.2 Measure Radiation Levels of Loaded MCO . $\quad$. 21

4.5 Cask Transfer $\quad . \quad$. $\quad$. $\quad$. $\quad . \quad$. $\quad . \quad 21$

4.5.1 Radiation Level Survey Prior to Transfer to CVD . $\quad 21$

4.5.2 Measure Temperature Rise After Cask Transfer to CVD 21

4.5.3 Measure Pressure Rise After Cask Transfer to CVD . 22

4.5.4 Gas Sample After Transfer to CVD . . . . 22

4.6 Bulk Water Removal $\quad . \quad$. $\quad$. $\quad$. $\quad$. $\quad 23$

4.6.1 Corrosion Power Test Before Bulk Water Removal . 23

4.6.2 Neutron and Gamma Survey of Cask Before and

After MCO Drain and Cask Drain . . . . $\quad 24$

4.6.3 Neutron and Gamma Survey of PWC Tank

Before and After MCO Bulk Water Drain . . $\quad 24$

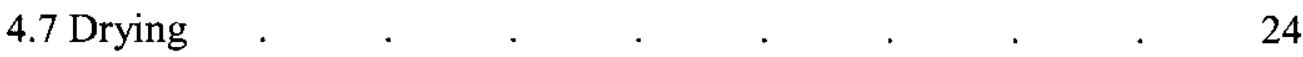

4.7.1 Gas Generation Rate During CVD . $\quad$. $\quad$. 24

4.7.2 Neutron and Gamma Survey Before Shipment From CVD 25

4.8 CSB Receipt . . . . . . . . . . $\quad$. 25

4.8.1 Neutron and Gamma Survey at CSB Receipt . . 25

4.9 Integrated Water Treatment System _ . . . . . $\quad 26$

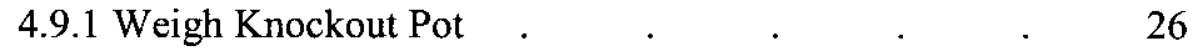

4.9.2 Sample IXM Inlet and Outlet . $\quad . \quad$. $\quad$. 26

4.9.3 IWTS Effluent Water Clarity Evaluation . $\quad$ - 27

4.9.4 Radiation Levels in IWTS $\quad . \quad$. $\quad . \quad$. 27

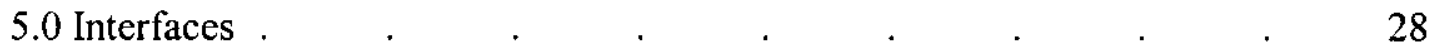

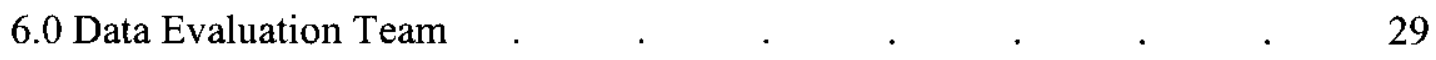

| 7.0 Implementation of Process Validation . $\quad . \quad \ldots \quad . \quad$. 30

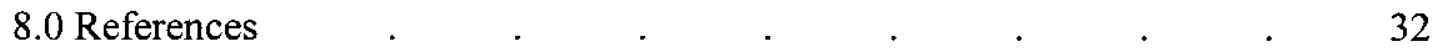




\subsection{PURPOSE}

The purpose of Process Validation is to confirm that nominal process operations are consistent with the expected process envelope. The Process Validation activities described in this document are not part of the safety basis, but are expected to demonstrate that the process operates well within the safety basis. Some adjustments to the process may be made as a result of information gathered in Process Validation. Excluded from the scope of this document are:

- Validation of Fuel Cleaning (which is an element of the safety basis and documented separately)

- Monitoring of MCOs in the CSB (which will not be used to make adjustments to the process)

- Cold Testing

- Normal Preoperational Acceptance Testing

- Routine Operations and Process Control

Specific objectives of Process Validation include:

- Surface Area - Demonstrate that the exposed fuel surface area in the MCO is well within the envelope assumed by models. Surface area directly influences thermal performance and gas generation, and is potentially influenced by retrieval and cleaning operations. This is perhaps the parameter of greatest interest in Process Validation.

- Gas Generation Rate - Demonstrate that gas generation rates in the MCO are within the envelope assumed in calculating pressure and gas composition.

- Reaction Rate - Determine the total reaction rate in the MCO, demonstrating the actual relationship between fuel surface area and total reaction rate.

- Scrap to Fuel Ratio - Determine the rate at which scrap (including whole elements that cannot be loaded into fuel baskets) is generated relative to fuel in fuel baskets. This ratio is important to the acceptability of the MCO and process design, which allows 0 to 2 scrap baskets per MCO, but assumes an average of 1 .

- Coarse to Fine Scrap Ratio - Determine the volume ratio of coarse to fine scrap. Coarse scrap is greater than 1" in size and must be loaded piece by piece into the scrap basket. Fine scrap is greater than $1 / 4$ " in size and may be dumped or poured into the fine scrap section of the scrap basket. Fine scrap has been limited to $10 \%$ of the volume of the scrap basket, to limit the total surface area feasible in any one scrap basket. The acceptability of this design and the number of MCOs produced with it will depend on the actual ratio of fine scrap created.

- Particulate - Confirm that the particulate in the MCO is well within the envelope assumed by models. The inventory of various forms of particulate influences the quantity of water assumed to remain in the MCO after drying. Particulate estimates are also used in dispersion calculations for accident conditions.

- Aluminum Hydroxide - Confirm that the inventory in the MCO cannot exceed the bounding value assumed in modeling. No credit is taken in modeling for cleaning of aluminum hydroxide. If cleaning removes the aluminum hydroxide coating, this 
should be able to be confirmed through a simple visual examination. Aluminum hydroxide is a contributor to water inventory in the MCO after drying.

- Radiological - Confirm dose rates associated with loaded MCOs.

- IXM usage - Confirm the rate at which IXMs will require changeout. This rate has been assumed in determining the number of IXMs needed by the project.

- Sludge Treatment Feed - Determine the feed to the Sludge Treatment system.

- Uranium Mass in Knockout Pot - Determine the rate of accumulation of uranium mass in the knockout pot. Limiting the mass of uranium metal in the knockout pot has been discussed as a possible method of assuring thermal stability of the knockout pot.

The scope of this document will include:

- Define the Process Validation steps required to gather the above information

- Identify the stages in Phased Startup Initiative and Fuel Processing Campaigns where Process Validation is required

- Identify any additional equipment that will be needed for Process Validation

- Identify any new procedures required and provide the basis for procedure preparation

- Identify other administrative activity needed to prepare for Process Validation

- State the number of measurements required for each step or the basis for determining that number in process 


\title{
2.0 CAMPAIGN SEQUENCE
}

Opportunities for Process Validation will be available during the Phased Startup Initiative (PSI) of the Fuel Retrieval System (FRS) and the Integrated Water Treatment System (IWTS), (Pajunen et. al., 2000) and during normal operations.

The PSI will process fuel through canister selection, fuel cleaning, sorting, and inspection. Fuel and scrap will be loaded, separately, back into canisters and returned to storage. Two phases of hot operations testing are proposed during the PSI, the first involving a minimum of 6 canisters of fuel (PSI, Phase 3), the second involving a minimum of 29 canisters of fuel (PSI, Phase 4).

Process Validation data will also be taken at selected points during full operations. Pajunen and Packer 1999 divides the loading of MCOs into the following groups.

\section{K West Basin}

Startup MkIV MCOs (18)

High Pu Blend MkIV MCOs (9)

Other MkIV MCOs (30)

Mk1A MCOs (146)

SPR MCO (1)

\section{K East Basin \\ Startup MkIV MCOs (7) \\ High Pu Blend MkIV MCOs (101) \\ Other MkIV MCOs (94)}

\begin{abstract}
The PSI will be the most advantageous time for Process Validation activities that involve examination of individual fuel elements or fuel canisters. The fuel selected for the PSI and that selected for the startup MCOs is believed to represent the range of fuel damage to be experienced throughout the basin population. Fuel damage is related to surface area, particulate, and scrap ratios. The fuel for PSI and the startup fuel will be taken from both aluminum and stainless steel canisters, providing the ability to observe the presence and behavior of aluminum hydroxide coatings, and fuel without the coating.
\end{abstract}

The PSI will not include loading of MCOs. Process Validation activities that observe loaded MCOs will be done primarily during the processing of the K West Startup MCOs. However, some observation of other fuel and other MCOs, including MCOs from the K East basin, will be required to complete process validation.

Process Validation data is desirable for MCOs that are destined for CSB monitoring. The following target MCOs will be selected for monitoring.

1) One $\mathrm{MCO}$ with minimal exposed fuel surface area and no aluminum hydroxide. 
2) One MCO with minimal exposed fuel surface area, but high in aluminum hydroxide

3) One MCO from KW high in exposed fuel surface area and scrap

4) One MCO from KE high in exposed fuel surface area and scrap

5) SPR Fuel

6) Additional MCOs could be included in the monitoring activity, if there are loadings of special interest identified, such as an MCO with two scrap baskets. 


\subsection{DATA SELECTION}

Table 1 lists the data collection steps that have been considered in support of Process Validation. Included in the table is an indication of how each of these possible data collection steps could be used to address the objectives of Process Validation. Lastly, the table recommends which steps should or should not be pursued as part of Process Validation. Following is a discussion of the recommended approach to providing the desired data for each of the major objectives of Process Validation.

\subsection{Surface Area}

Detailed visual examination of the fuel and scrap after cleaning during the PSI will provide an assessment of surface area. This examination should be correlated with a visual examination of the top of the canister after cleaning to determine the extent to which fuel damage can be assessed from the top of the canister. This will then be used to assess fuel damage during operations by visual examination of the top of loaded fuel. These assessments, in turn, will be compared to results from the corrosion power test (see Section 4.6.1) and the gas generation rate during CVD (see Section 4.7.1), which provide an indication of the total reaction taking place in the MCO. Detailed examination of fuel elements will be performed for all fuel included in the PSI. Only limited detailed visual examination of elements will be required after that. Examination of loaded baskets, corrosion power tests, and gas generation testing, are recommended until a range of values is demonstrated. All MCOs proposed for monitoring in the CSB will be included in these tests.

Visual examination of the fuel prior to cleaning will be limited to looking at the top of the canister and to those lift and look observations that have already been made. This is due to the fact that separating elements prior to cleaning may influence the cleaning performance that needs to be assessed during the PSI.

Gas and liquid sampling from the canister, which were done to pinpoint damaged fuel during characterization, are not recommended as part of Process Validation, as they provide less information than visual examination of the fuel. Measuring the sludge depth in the canister is also not recommended, as the data provided is of limited value.

\subsection{Gas Generation Rate}

The surface area observations described above will provide some correlation to gas generation in a loaded MCO. In addition, pressure and temperature rise after cask transfer to CVD, and a gas sample after cask transfer to CVD, should be taken to confirm the gas generation rate during shipping. 


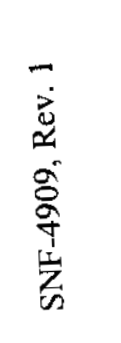

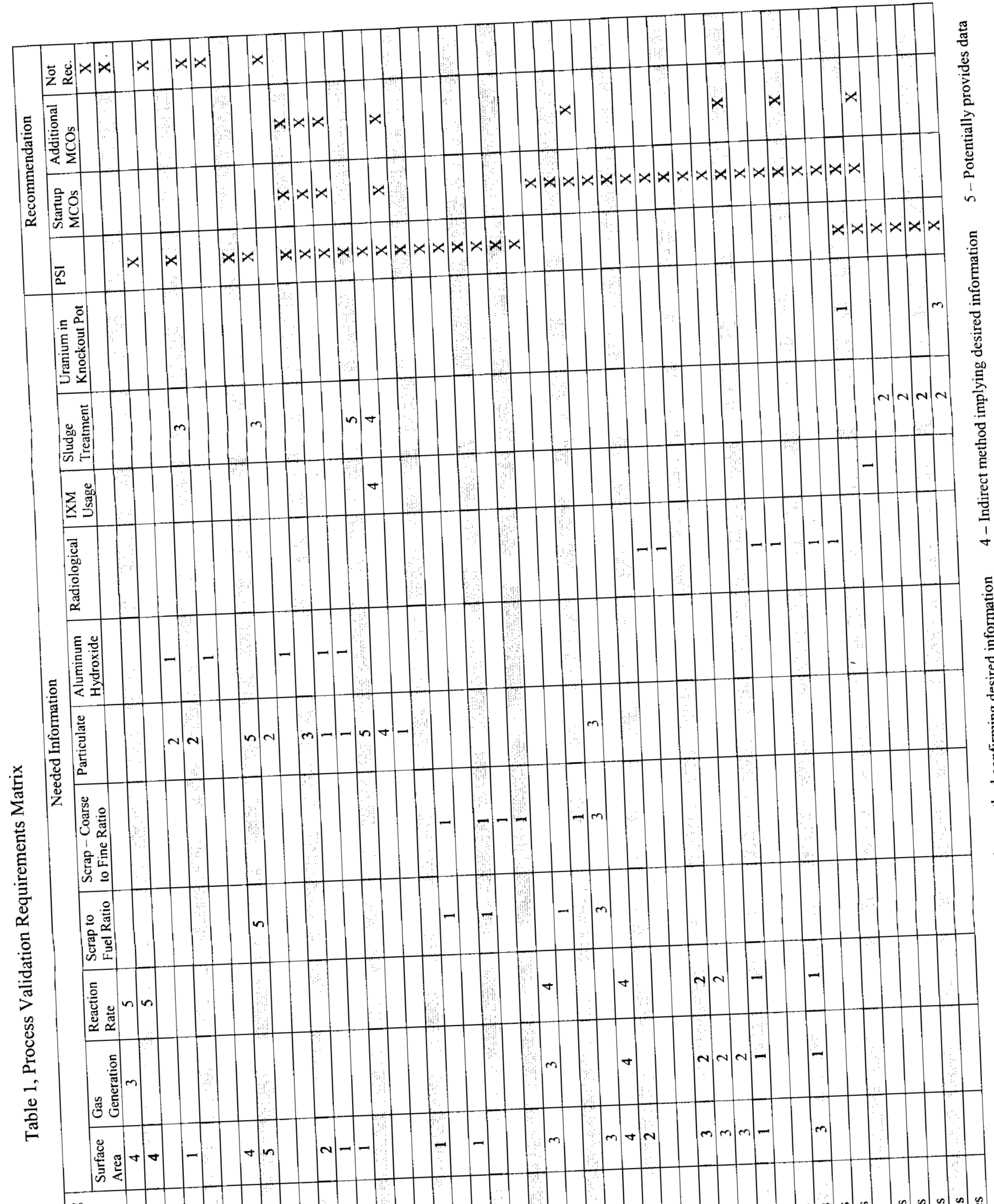

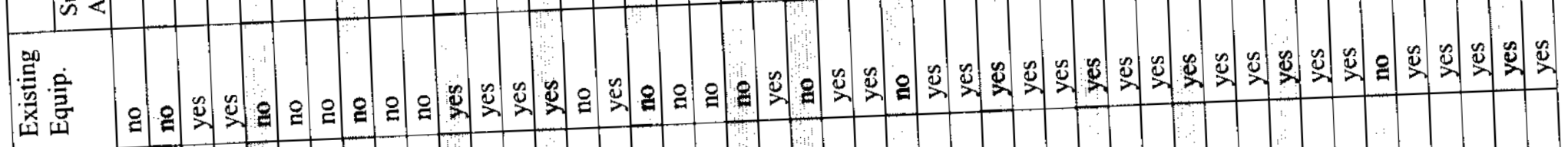
送

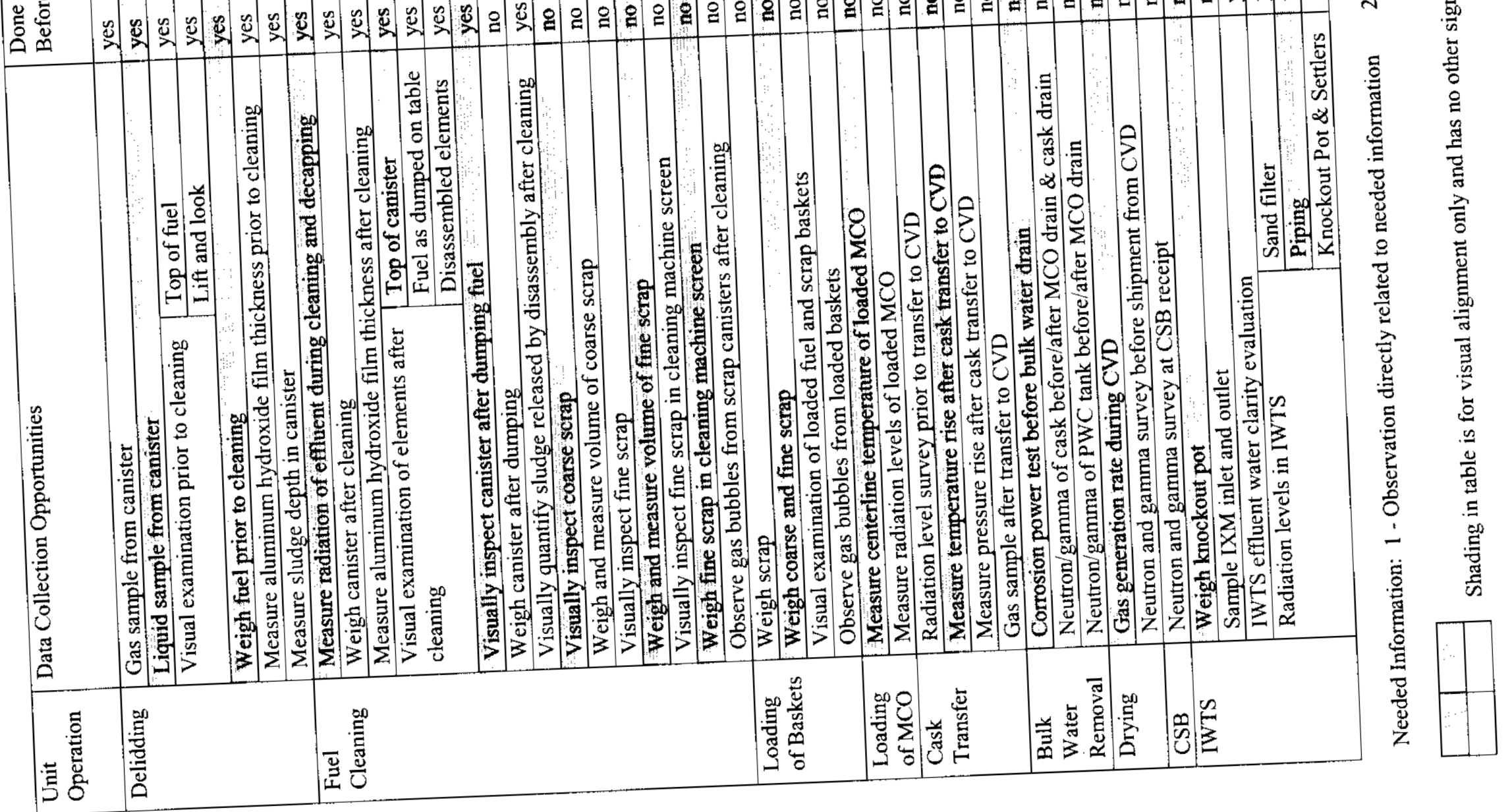




\subsection{Reaction Rate}

The testing described above will define the surface area for the MCO. The corrosion power test provides the best assessment of the total reaction taking place in the MCO. This total reaction is a function of both the surface area and the reaction rate.

\subsection{Scrap to Fuel Ratio}

A ratio can be established during the PSI, by weighing fuel and scrap returned to canisters after cleaning. The ratio then will be reviewed during the loading of actual MCOs to verify that the total number of MCOs projected will be within the allocated number of storage positions.

\subsection{Coarse to Fine Scrap Ratio}

A ratio can be established during the PSI, by weighing fine and coarse scrap returned to canisters after cleaning. The ratio then will be reviewed during the loading of actual MCOs verify that the fines capacity of scrap baskets is sufficient to support predicted routine operations.

\subsection{Particulate}

The quantity of particulate loaded into the MCO and that removed from the fuel will be estimated during the PSI by visual examination of fuel assemblies, weighing of the fuel before and after cleaning, and validation of the cleaning process by disassembly of the assemblies. It is anticipated that validation activities during the PSI will establish that particulate inventories are well within the expected envelope and that additional validation during operations will not be required. Periodic disassembly is required as part of the cleaning process validation procedure during routine operations.

A mass balance will be performed during the PSI by weighing the canister before cleaning, after cleaning, and after dumping. Scrap canisters will be weighed after additions of coarse scrap, fine scrap from the table, and fine scrap from the cleaning machine screen. The knockout pot in the Integrated Water Treatment System will also be weighed.

\subsection{Aluminum Hydroxide}

Visual examinations after cleaning, during the PSI, will indicate whether or not aluminum hydroxide coatings are removed during cleaning and whether any remaining coatings observed are consistent with those observed during characterization when measurements were taken. No additional validation during operation is planned. 


\subsection{Radiological}

Modeling was used to determine dose rates for design and planning. Radiological readings of loaded MCOs will be taken at each step of the process to confirm modeling predictions.

\subsection{IXM Usage}

The IXM usage will be projected by sampling the inlet and outlet of the IXMs during key process steps during the PSI, and by analyzing water drained from MCOs. IXM inlet and outlet sampling will also be done during the other phases of the project.

\subsection{Sludge Treatment Feed}

An assessment of the feed that will be sent to sludge treatment will be provided by the mass balance described above, by analysis of water drained from MCOs, and by measuring the radiation levels of IWTS components.

\subsection{Uranium Mass in Knockout Pot}

Weighing the knockout pot during the PSI will provide a basis, if needed, for controlling accumulations in the knockout pot. This weighing will also be used in the mass balance discussed above. 


\subsection{DETAILED SCOPE}

\subsection{Delidding}

\subsubsection{Visual Examination Prior to Cleaning}

Sequence - No lift and look observations will be made beyond what have already been made. This is to avoid skewing the results of cleaning validation, since the separation of elements may displace particulate within an assembly. Visual examination of the top of each canister of fuel will be done after delidding, for all fuel included in the PSI. No visual observations of fuel prior to cleaning are planned after the PSI.

Method - A hard copy, taken from a video camera, will be made of the top of each canister.

Criteria/Data Use - Photographs and video records will be used by the Data Evaluation Team to establish the following correlations:

- Precleaning view of top of canisters to pre-cleaning lift and look records (to attempt to make an estimate of fuel damage and

- Precleaning view of top of canisters to post cleaning view of top of canisters (to evaluate the effect of the cleaning machine)

- The post cleaning view of the top of canisters will in turn be compared with more detailed visual examinations following cleaning.

Expected Range - The bounding value for exposed fuel surface area for a fuel basket is $7,900 \mathrm{~cm}^{2}$. This equates to $146 \mathrm{~cm}^{2}$ per fuel assembly. The geometric surface area of an intact full length, Mark IV, fuel assembly is $3156 \mathrm{~cm}^{2}$. The expected result of visual examinations is that at least $50 \%$ of outer elements and $85 \%$ of inner elements will be intact before and after cleaning. For pre-cleaning observations to be useful, there must not be significant fuel damage during cleaning, and there must be good correlation between damage observable from the top of the canister to total damage observable from detailed visual examinations.

Requirements - Equipment will need to be in place to take the videos and hard copies. There are no new requirements associated with this step.

\subsubsection{Weigh Fuel Prior to Cleaning}

| Sequence - During the PSI, each canister of fuel will be weighed prior to cleaning.

Method - A scale accurate to within less than $1 \%$ will be used to weigh each canister.

Criteria/Data Use - The weight of the canister will be used to produce a mass balance for each of the canisters during the PSI. Estimates of particulate collected in the IWTS will be based on this mass balance. 
Expected Range - The total weight of a canister prior to cleaning will be in the range of 350 to $400 \mathrm{~kg}$.

Requirements - The scale will need to be available and procedures that include the weighing step will need to be prepared.

\subsection{Fuel Cleaning}

\subsubsection{Measure Radiation of Effluent During Cleaning and Decapping}

Sequence - These measurements will be taken during the PSI. The measurement during cleaning will be used to establish an understanding of the cleaning cycle and provide a tool for optimizing the cleaning cycle time should fuel damage during cleaning become an issue. The measurement during decapping will be used to confirm assumptions made in IWTS development.

Method - A monitor will be placed on the effluent line with a continuous reading during cleaning and decapping.

Criteria/Data Use - Optimization of cleaning time could be done if fuel damage during cleaning becomes an issue. The IWTS assumed a maximum cesium concentration based on flushing in the decapper being spread over 3 minutes.

Expected Range - Intact fuel in the K West basin is not expected to have significant material removed and therefore no significant radiation from the effluent. For this technique to have value there must be a measurable drop in radiation from the effluent when particulate has been removed from the fuel. The actual value of the readings will depend on the placement of the monitor and the amount of material being removed by the process.

Requirements - A radiation monitor attached to a strip chart or equivalent recording device will be needed. The operating procedure will need to include obtaining the reading.

\subsubsection{Weigh Canister After Cleaning}

Sequence - During the PSI, each canister of fuel will be weighed after cleaning.

Method - A scale accurate to within less than $1 \%$ will be used to weigh each canister. Canister weighing requires an extra step. The canister will have to be moved to the process table to be weighed with the scale.

Criteria/Data Use - The weight of the canister will be used to produce a mass balance for each of the canisters during the PSI. Estimates of particulate collected in the IWTS will be based on this mass balance. 
Expected Range - The total weight of a canister after cleaning will be in the range of 350 to $400 \mathrm{~kg}$. The amount of material removed by the cleaning machine will vary significantly by canister, depending on fuel condition. $\mathrm{K}$ West canisters with intact fuel are not expected to have measurable material removed by the cleaning process.

Requirements - The scale will need to be available and procedures that include the weighing step will need to be prepared.

\subsubsection{Visual Examination of Fuel After Cleaning}

Sequence - The top of the fuel will be video taped for all canisters in the PSI, startup MCOs from the K West Basin, and canisters that are expected to be loaded into monitored MCOs. Fuel and scrap will be video taped after being dumped on the table for all canisters in the PSI, startup MCOs from the K West Basin, and canisters that are expected to be loaded into monitored MCOs. Complete visual examination of disassembled fuel will be done only for those assemblies in the PSI. Real time observation of the examination of disassembled fuel by the Data Evaluation Team is planned.

Method - A hard copy, taken from a video camera, will be made for observations of tops of baskets and dumped fuel, so that the information will be available to the Data Evaluation Team. Video records will be made of disassembled fuel. The purpose of disassembly is to inspect for the quantity of canister particulate. This validation step supports the safety basis and is considered outside the scope of this document.

Criteria/Data Use - Estimates of fuel damage and particulate will be made from all the observations. Correlations will be made between pre and post cleaning observations of the top of the canister to assess the impact of the cleaning process on the fuel.

Expected Range - The bounding value for reactive fuel surface area for a fuel basket is $7,900 \mathrm{~cm}^{2}$. This equates to $146 \mathrm{~cm}^{2}$ per fuel assembly. The geometric surface area of an intact full length, Mark IV, fuel assembly is $3156 \mathrm{~cm}^{2}$. The bounding value for oxide film and adhering particulate mass in a fuel basket is $1.16 \mathrm{~kg}$ or $21 \mathrm{~g}$ per assembly. Visual observations of fuel can be correlated to fuel that was previously examined for particulate mass. Since the bounding particulate was based on the worst element observed, and a majority of elements are intact, actual fuel is expected to average significantly less particulate that the bounding value.

Requirements - Equipment will need to be in place to take the videos. There are no new requirements associated with this step.

\subsubsection{Visually Inspect Canister After Dumping}

Sequence - During the PSI a visual examination of the inside of each canister will be made, after the fuel is dumped. 
Method - A hard copy, taken from a video camera will be made.

Criteria/Data Use - This step is to determine whether any debris, canister particulate, or fuel is left in the canister after dumping. This observation will support the mass balance to be done on canisters.

Expected Range - After dumping, the canister is expected to be empty, free of fuel, sludge, and debris, and is expected to be undamaged by the cleaning process.

Requirements - Equipment will need to be in place to take the videos. There are no new requirements associated with this step.

\subsubsection{Weigh Canister After Dumping}

Sequence - During the PSI, each canister will be weighed after the fuel is dumped.

Method - A scale accurate to within less than $1 \%$ will be used to weigh each canister.

Criteria/Data Use - The weight of the canister will be used to produce a mass balance for each of the canisters during the PSI. Estimates of particulate collected in the IWTS will be based on this mass balance.

Expected Range - Canister weight will vary depending on canister type, but will be $10 \%$ or less of the full canister weight.

Requirements - The scale will need to be available and procedures that include the weighing step will need to be prepared.

\subsubsection{Visually Quantify Sludge Released by Disassembly After Cleaning}

This activity supports the project safety basis and is considered outside the scope of this document. The procedure is described in Stegen, 2000.

\subsubsection{Visually Inspect Coarse Scrap}

Sequence - During the PSI, coarse scrap will be loaded back into canisters. Coarse scrap will be observed while on the table and as it is being loaded into the canisters.

Method - The sorting and loading of coarse scrap will be video taped. Computer analysis of the video image will be done to estimate fuel surface area on the scrap.

Criteria/Data Use - An estimate of the surface area on coarse scrap will be compared to estimates used in modeling, and the operation will be evaluated to assure that smaller pieces of scrap are not being loaded into the coarse section of the scrap basket. 
Expected Range - Coarse scrap is expected to range from 1" pieces to complete elements that are damaged and will not fit into a fuel basket. Scrap throughout this range is acceptable. The bounding surface area for a scrap basket is $45,000 \mathrm{~cm}^{2}$. Actual scrap baskets are expected to contain significantly less than this amount.

Requirements - Video equipment and appropriate software to estimate surface area will need to be in place.

\subsubsection{Weigh and Measure Volume of Coarse Scrap}

Sequence - During the PSI, coarse scrap will be loaded back into canisters. Scrap will be kept separate by key. There are three keys included in the PSI, requiring at least three scrap canisters. Each canister will need to be weighed empty and then weighed after the addition of coarse scrap. The volume of scrap in the canister will also be measured.

Method - A scale accurate to within less than $1 \%$ will be used to weigh each canister after scrap addition. The distance to the top of the scrap will be measured with a ruler with a plate on the end of it.

Criteria/Data Use - The ratio of scrap to fuel will be determined during the PSI to project the number of scrap baskets needed per MCO. The process has been designed assuming an average of one scrap basket per MCO, but the MCO can accept 0,1 , or 2 scrap baskets. If the ratio of scrap to fuel is unacceptably high, adjustments to the process will be considered where practical.

Expected Range - The amount of coarse scrap to be generated is unknown at this time, but for the SNF process to be successful, coarse scrap will need to be less that $20 \%$ of the initial fuel mass.

Requirements - The scale will need to be available and procedures that include weighing canisters before and after scrap addition will need to be prepared.

\subsubsection{Visually Inspect Fine Scrap}

Sequence - During the PSI, fine scrap will be loaded back into canisters. Fine scrap will be observed while on the table and as it is being loaded into the canisters.

Method - The collection and loading of fine scrap will be video taped. Computer analysis of the video image will be done to estimate fuel surface area on the scrap.

Criteria/Data Use - An estimate of the surface area on fine scrap will be compared to estimates used in modeling, and the operation will be evaluated to assure that an excessive number of pieces smaller than $1 / 4$ " are not being loaded into the fine section of the scrap basket. 
Expected Range - Fine scrap is expected to range from $1 / 4$ " to 1 " with a negligible quantity of finer material. Scrap throughout this range is acceptable. Larger pieces are also acceptable in the fine section of the scrap basket.

Requirements - Video equipment and appropriate software to estimate surface area will need to be in place.

\subsubsection{Weigh and Measure Volume of Fine Scrap}

Sequence - During the PSI, fine scrap will be loaded back into the same canisters as the coarse scrap, but kept separate by key. Each canister will need to be weighed before and after the addition of fine scrap.

Method - A scale accurate to within less than $1 \%$ will be used to weigh each canister before and after fine scrap addition. The distance to the top of the scrap will be measured with a ruler with a plate on the end of it.

Criteria/Data Use - The ratio of fine scrap to coarse scrap will be used to project the volume of fine scrap to be created by the process. The process has been designed allowing for up to $10 \%$ of the volume of the scrap basket to be occupied by fine scrap. It is acceptable to place coarse scrap in the fines portion of the scrap basket, but unacceptable to place fines in the coarse section of the scrap basket. If the ratio of fine scrap to coarse scrap is too high, adjustments to the process will be considered where practical.

Expected Range - The amount of fine scrap to be generated is unknown at this time, but for the SNF process to be successful, fine scrap needs to be limited to about $2 \%$ of the initial fuel mass.

Requirements - The scale will need to be available and procedures that include weighing canisters before and after scrap addition will need to be prepared.

\subsubsection{Visually Inspect Fine Scrap in Cleaning Machine Screen}

Sequence - During Phase 3 of the PSI, the Primary Cleaning Machine will be cleaned out after processing each canister. The fine scrap collected on the cleaning machine wash basket and strainer will be dumped on a grid on the process table and photographed and will be used to obtain a size estimate of the material. Visual inspections of the material in the wash basket and strainer will also be done during Phase 4 of the PSI, but Phase 3 testing will be used to determine the frequency of cleanout during Phase 4 the PSI.

Method - A hard copy, taken from a video camera will be made.

Criteria/Data Use - The data will be used to assess the tendency to blinding of the strainer and accumulation of material smaller than $1 / 4$ ". Periodic cleaning of the Primary 
Cleaning Machine is necessary to assure that the small material is not routinely loaded into the fines portion of the scrap basket.

Expected Range - The quantity and distribution of material collected on the cleaning machine wash basket and strainer is unknown at this time.

Requirements - Equipment will need to be in place to take the videos. There are no new requirements associated with this step.

\subsubsection{Weigh Fine Scrap in Cleaning Machine Screen}

Sequence - During the PSI, the fine material in the Primary Cleaning Machine strainer will be weighed each time the machine is cleaned.

Method - The cleaning machine strainer will be weighed before use and after removal for each cleanout. This scale is accurate to within less than $1 \%$.

Criteria/Data Use - The fine scrap accumulated in the cleaning machine will be considered part of the total quantity of fine scrap which needs to be estimated as explained above.

Expected Range - The weight of material collected on the cleaning machine wash basket and strainer is unknown at this time. However, this is one of two sources of fine scrap which should not exceed $2 \%$ of the initial fuel mass.

Requirements - A location needs to be identified to place the strainer for weighing. A procedure will be need to be developed for this weighing.

\subsubsection{Observe Gas Bubbles From Scrap Canisters After Cleaning}

Sequence - There will be 3 keys involved in the PSI, with scrap kept separate by keys loaded into canisters separate from fuel. There will be, therefore a minimum of 3 scrap canisters (more if volume requires) comprised of scrap that has been through the cleaning process. Observations of these canisters will be made.

Method - Video records will be made of any bubbling from the scrap canisters. A computer analysis of the video image will be done to convert bubble observations to an estimated gas generation rate.

Criteria/Data Use - An estimate of the reaction rate will be made from the bubbling from scrap canisters and compared to expected values for reaction rate and surface area for the scrap.

Expected Range - Some canisters of bad fuel have been observed to release bubbles as often as twice a minute. The scrap basket has an approximate volume of 170 liters, with a bounding surface area of $45,000 \mathrm{~cm}^{2}$ and an expected surface area of $17,000 \mathrm{~cm}^{2}$. The 
approximate volume of one barrel of a fuel canister is 21 liters, and would therefore be expected to have an approximate fuel surface area of $2100 \mathrm{~cm}^{2}$ if filled with representative scrap. At the basin temperature of $50^{\circ} \mathrm{F}\left(10^{\circ} \mathrm{C}\right)$ the scrap would be expected to oxidize at a rate of $.001 \mathrm{mg}$ weight gain $/ \mathrm{hr}-\mathrm{cm} 2$ (from figure $2-1$ of Pajunen 1999).

$.001 \mathrm{mg} / \mathrm{hr}-\mathrm{cm} 2 * 2100 \mathrm{~cm} 2=2.1 \mathrm{mg} / \mathrm{hr}$

Assuming $\mathrm{U}+2 \mathrm{H}_{2} \mathrm{O}>\mathrm{UO}_{2}+2 \mathrm{H}_{2}$

$32 \mathrm{mg}$ of weight gain would result in $4 \mathrm{mg}$ of hydrogen release.

Therefore the gas release rate from a barrel of scrap would be

$2.1^{*}(4 / 32)=0.26 \mathrm{mg} / \mathrm{hr}$.

Assuming $22.4 \mathrm{l} / \mathrm{mole}$ (at STP), this would convert to:

$0.26 \mathrm{mg} / \mathrm{hr} / 2000 \mathrm{mg} / \mathrm{mole} * 22400 \mathrm{ml} / \mathrm{mole}=2.9 \mathrm{ml} / \mathrm{hour}$, a small, but observable source of bubbles.

Requirements - Video equipment and appropriate software to estimate the gas generation rate will need to be in place and devoted to the scrap canisters for periods up to 24 hours per canister. A location to place the canister without a lid, and with a dedicated video will be required.

\subsection{Loading of Baskets}

\subsubsection{Weigh Scrap}

Sequence - The weight of loaded scrap baskets will be taken for all scrap baskets loaded for the 18 Startup Mark IV MCOs.

Method - Each basket will be weighed using a load cell on a stiffback. The load cell is accurate to within $1 \%$. Ordinarily, baskets can be weighed when they are being moved. However, scrap baskets will initially need to be weighed more frequently than they are moved.

Criteria/Data Use - The data will be used to project the number of scrap baskets needed to complete the project. This information is needed to project the number of MCOs and the appropriateness of the process design, which assumes an average of 1 scrap basket per MCO.

Expected Range - The weight of uranium is limited to $980 \mathrm{~kg}$ in a Mark IV scrap basket and $1265 \mathrm{~kg}$ in a Mark IV fuel basket. Fuel baskets will be corrected for buoyancy and for cladding and end caps. Scrap basket weighing will be corrected for buoyancy by assuming everything in the basket is uranium, as described in Duncan and Sexton, 1998.

Requirements - The load cell will need to be available for this procedure. 


\subsubsection{Weigh Coarse and Fine Scrap}

Sequence - For the first 3 Startup Mark IV MCOs, the scrap basket will be weighed before and after each addition of fine scrap and after all scrap is loaded. A video record of the scrap addition will be taken for use in interpreting the results.

Method - The scrap basket will be weighed in the same manner as full baskets. This procedure will require more weighings of the first three scrap baskets.

Criteria/Data Use - The data will be used to confirm the appropriateness of the scrap basket design, which allows $10 \%$ of the volume for fine scrap, and to estimate the exposed fuel surface area in the scrap basket.

Expected Range - The ratio of fine scrap to coarse scrap is not known, but a ratio of less than $10 \%$ by volume is the basis of the design and is expected.

Requirements - The load cell to weigh baskets and a video camera covering the scrap loading will be required.

\subsubsection{Visual Examination of Loaded Fuel and Scrap Baskets}

Sequence - Visual examination of baskets after they are fully loaded will be done for all Startup Mark IV MCOs. They will also be done for all baskets in each MCO selected for monitoring in the CSB, and at least one fuel and one scrap basket representing one MCO from each additional category in the Campaign Plan, (Pajunen and Packer 1999).

Method - A hard copy, taken from a video camera will be made.

Criteria/Data Use - The condition of the fuel in a loaded basket will be used to correlate with other assessments of fuel surface area and particulate. The objective will be to obtain a basis for estimating fuel surface area and particulate only by looking at the top of a loaded basket.

Expected Range - The bounding value for reactive fuel surface area for a fuel basket is $7,900 \mathrm{~cm}^{2}$. This equates to $146 \mathrm{~cm}^{2}$ per fuel assembly. The surface area of a full length, Mark IV, fuel assembly is $3156 \mathrm{~cm}^{2}$. The expected result of visual examinations is that at least $50 \%$ of outer elements and $85 \%$ of inner elements will be intact after loading. For fuel basket observations to be useful there must be good correlation between damage observable from the top of the basket to total damage observable from detailed visual examinations. Scrap basket observations will be harder to quantify, but the general distribution of whole elements that would not fit in fuel basket, small pieces in the coarse section of the basket, and fine scrap will be observable from the top of the basket.

Requirements - A video camera will need to be available for this observation. There are no new requirements. 


\subsubsection{Observe Gas Bubbles From Loaded Baskets}

Sequence - Selected loaded fuel baskets from Startup Mark IV MCOs will be observed for bubbling after loading. No delays in loading of MCOs will be imposed by this requirement.

Method - Video records of loaded baskets, prior to loading into the MCO will be made and evaluated for bubbling. A computer analysis of the video image will be done to convert bubble observations to an estimated gas generation rate.

Criteria/Data Use - Correlations will be made of the presence and rate of bubbling with the estimated surface area. Also calculations of the reaction rate will be made, based on the observed rate of bubbling. The objective will be to determine if observed bubbling is a reliable indicator of reaction rate and if reaction rates observed are within expected ranges.

Expected Range - The expected fuel surface area in a scrap basket is $17,000 \mathrm{~cm} 2$. This equates to an estimated gas generation rate of $2.1 \mathrm{mg} / \mathrm{hr}$ or $24 \mathrm{ml} /$ hour at STP. A fuel basket has an expected surface area of only $425 \mathrm{~cm} 2$, but a bounding value of $7,900 \mathrm{~cm} 2$. These values would produce expected gas generation rates of $0.05 \mathrm{mg} / \mathrm{hr}$ and $0.99 \mathrm{mg} / \mathrm{hr}$ respectively.

Requirements - A video camera equipment and appropriate software to estimate the gas generation rate will be required for this purpose.

\subsection{Loading of MCO}

\subsubsection{Measure Centerline Temperature of Loaded MCO}

Sequence - The first available fully loaded MCO will have a centerline temperature measurement.

Method - A thermocouple will be placed down the center of the baskets to about 2 feet above the bottom of the MCO. This measurement will be taken just prior to placement of the MCO shield plug.

Criteria/Data Use - The temperature differential between the MCO centerline and the basin water temperature will be compared to a predicted value and used in calculations of temperature rise and gas generation during transport to CVD.

Expected Range - Thermal calculations of wet transport were based on the assumption that the entire $\mathrm{MCO}$ is at uniform temperature prior to shipping. This measurement is expected to confirm a negligible temperature differential within the $\mathrm{MCO}$ prior to closure. 
Requirements - A thermocouple which can be lowered into the MCO and an appropriate procedure will be required.

\subsubsection{Measure Radiation Levels of Loaded MCO}

Sequence - Radiation levels will be measured for the first three fully loaded MCOs.

Method - A neutron and gamma survey will be made while the baskets are being loaded into the MCO. A neutron and gamma survey will be made while the cask/pail/MCO assembly is about 3 feet from the surface of the water and continuing until the pail is in the resting position.

Criteria/Data Use - The data will be used to confirm dose rate modeling by comparing actual values to calculated values.

Expected Range - Dose rate expectations are described in Lorenz, 1999.

Requirements - A procedure for these measurements will need to be developed by Health Physics and gamma and neutron monitors will be required.

\subsection{Cask Transfer}

\subsubsection{Radiation Level Survey Prior to Transfer to CVD}

Sequence - Radiation levels prior to transfer to CVD will be measured for the first three fully loaded MCOs.

Method - A neutron and gamma shipping survey above and around the cask/transporter as well as in the truck cab will be made and a comprehensive smear survey of the cask exterior will be performed. Smear samples of all MCOs will be taken as a matter of normal operations. The first three will be considered Process Validation and will be more comprehensive.

Criteria/Data Use - The data will be used to confirm dose rate modeling by comparing actual values to calculated values.

Expected Range - Dose rate expectations are described in Lorenz, 1999.

Requirements - No new requirements.

\subsubsection{Measure Temperature Rise After Cask Transfer to CVD}

Sequence - The cask annulus temperature will be measured for the first three casks transferred to CVD. 
Method - When the cask is connected for purging, the gas temperature will be measured. When the tempered water system is connected to the cask annulus, the temperature of the water exiting the annulus will also be measured. Both of these values, cask water temperature and cask gas temperature will be used. Transfer conditions, including time, temperature, and solar input will need to be recorded.

Criteria/Data Use - The temperature measurements will be compared to values predicted from modeling. In addition to the first three casks, recommendation may be made to take additional temperature data from a high decay heat MCO transferred during hot weather. Since this temperature data is taken from connections made to purge the cask and to circulate tempered water, no additional operational steps are required to take these temperature readings.

Expected Range - The cask annulus temperature is expected to rise approximately $10^{\circ} \mathrm{C}$ during an 8-hour transfer on a hot day.

Requirements - The current design includes temperature indicators on the line from the cask lid connection and on the tempered water outlet.

\subsubsection{Measure Pressure Rise After Cask Transfer to CVD}

Sequence - The cask pressure will be measured at CVD receipt for the first three casks transferred to CVD.

Method - A cask lid connection will be made to purge the cask. There is a pressure indicator in this line that will be read prior to purging the cask.

Criteria/Data Use - The pressure measurements will be compared to values predicted from modeling. In addition to the first three casks, recommendation may be made to take additional pressure data from a high decay heat MCO transferred during hot weather. Since this pressure data is taken from connections made to purge the cask, no additional operational steps are required to take these temperature readings.

Expected Range - The cask pressure is expected to rise approximately 5 psi during an 8hour transfer on a hot day.

Requirements - The current design includes a pressure indicator on the line from the cask lid connection.

\subsubsection{Gas Sample After Transfer to CVD}

Sequence - A gas sample from the cask annulus will be taken from each of the first three casks transferred to CVD, prior to purging of the cask at CVD receipt.

Method - An evacuated sample cartridge of approximately 0.5 liters volume will be placed in the purge line at the connection provided for that purpose. The sample will be 
considered radioactive and sent to the laboratory and analyzed for hydrogen, xenon, and nitrogen.

Criteria/Data Use - The gas sample data will be used to evaluate the extent of uranium oxidation reaction that has taken place during transport of the cask/MCO to CVD. This will be compared to predictions based on modeling.

Expected Range - The total hydrogen present after an 8-hour transfer is expected to be less than half the initial helium backfill quantity. Xenon is expected to be approximately 4 orders of magnitude less than hydrogen (the exact ratio varies by fuel burnup) and is an indicator that the hydrogen is from fuel oxidation. Nitrogen is not expected and would be an indicator of air inleakage.

Requirements - The capability to sample gas is included in the existing design. A procedure will need to be in place for the sampling and handing of the sample.

\subsection{Bulk Water Removal}

\subsubsection{Corrosion Power Test Before Bulk Water Drain}

Sequence - The corrosion power test will be performed at least on the MCOs designated for CSB monitoring. Because this test will tie up the cask and transporter for as much as half a day, the number of tests will otherwise be kept as low as feasible.

Method - After heating the MCO to $45^{\circ} \mathrm{C}$ using the tempered water system, a helium sparge is initiated and the vacuum pump started. The helium flowrate will be $1.5 \mathrm{scfm}$. At about half-hour intervals, the concentration of hydrogen and xenon in helium is measured using the RGA unit until their relative concentrations are consistent with expectations.

Criteria/Data Use - The total uranium oxidation rate for the loaded MCO will be determined with this test and compared to values predicted from modeling.

With a low flow of inert gas and a several hour hold time, the measurement sensitivity should be adequate to validate the projected average corrosion rate in water at $45^{\circ} \mathrm{C}$, which supports the assumptions used in developing the safety basis limits.

Expected Range - Nominal values for expected corrosion are as follows:

\begin{tabular}{|l|c|}
\hline Surface Area, $\mathrm{m}^{2} / \mathrm{MCO}$ (with 1 scrap basket) & 1.9 \\
\hline Hydrogen Release Rate at $45^{\circ} \mathrm{C}(\mathrm{mol} / \mathrm{sec})$ & $4.6 \times 10^{-6}$ \\
\hline Hydrogen Concentration (ppm, with $1.1 \mathrm{scfm}$ He flowrate) & 146 \\
\hline $\begin{array}{l}\text { Xenon concentration (ppb, } 12 \% \text { Pu fuel has } 1.3 \mathrm{gmol} \\
\text { Xe/MTU) }\end{array}$ & 23 \\
\hline
\end{tabular}

Requirements - A procedure for this test will need to be prepared. 


\subsubsection{Neutron and Gamma Survey of Cask Before and After MCO Drain and Cask Drain}

Sequence - The first three MCOs will have readings taken.

Method - Neutron and gamma surveys of the cask will be taken before and after draining the $\mathrm{MCO}$ and before and after draining the cask.

Criteria/Data Use - The data will be used in conjunction with surveys of lines and equipment to assess the accumulation of particulates and to confirm that neutron dosimetry will not be permanently needed by facility staff.

Expected Range - Dose rate expectations are described in Lorenz, 1999.

Requirements - No new requirements

\subsubsection{Neutron and Gamma Survey of PWC Tank Before and After MCO Bulk Water Drain}

Sequence - Readings will be taken for the first three MCOs drained.

Method - Neutron and gamma surveys of the PWC tank will be taken before and after draining the MCO.

Criteria/Data Use - The data will be used in conjunction with surveys of the cask to assess the accumulation of particulates and to confirm that neutron dosimetry will not be permanently needed by facility staff.

Expected Range - Dose rates will depend on the accumulation of particulates.

Requirements - No new requirements

\subsection{Drying}

\subsubsection{Gas Generation Rate During CVD}

Sequence - These readings will be taken on all MCOs that were subject to the corrosion power test. Because this test does not significantly impact the operating time, the gas generation rate for additional MCOs of interest may be taken, up to as many as 24 MCOs.

Method - The flowrate for the helium purge will be recorded and the concentration of hydrogen, xenon, and nitrogen, will be measured in the helium purge using the RGA Unit. 
Criteria/Data Use - This data will be used to determine the total MCO reaction under low pressure water vapor conditions. These results can be compared to data from flooded conditions. Both results will be compared to predictions based on modeling.

Expected Range - Concentrations of hydrogen and xenon are expected to be in a similar range as the corrosion power test. Nitrogen is not expected and would be an indicator of air inleakage.

Requirements - A procedure for this test will need to be prepared.

\subsubsection{Neutron and Gamma Survey Before Shipment From CVD}

Sequence - The first three MCOs will require this survey.

Method - A neutron and gamma shipping survey above and around the cask/transporter as well as in the truck cab will be made and a comprehensive smear survey of the cask exterior. Smear samples of all MCOs will be taken as a matter of normal operations. The first three will be considered Process Validation and will be more comprehensive.

Criteria/Data Use - The data will be used to confirm dose rate modeling by comparing actual values to calculated values.

Expected Range - Dose rate expectations are described in Lorenz, 1999.

Requirements - No new requirements

\subsection{CSB Receipt}

\subsubsection{Neutron and Gamma Survey at CSB Receipt}

Sequence - The first three MCOs will require this survey.

Method - A neutron and gamma shipping survey above and around the cask/transporter as well as in the truck cab will be made and a comprehensive smear survey of the cask exterior. Smear samples of all MCOs will be taken as a matter of normal operations. The first three will be considered Process Validation and will be more comprehensive.

Criteria/Data Use - The data will be used to confirm dose rate modeling by comparing actual values to calculated values.

Expected Range - Dose rate expectations are described in Lorenz, 1999.

Requirements - No new requirements 


\subsection{Integrated Water Treatment System}

\subsubsection{Weigh Knockout Pot}

Sequence - The knockout pot will be weighed after each fuel wash batch during PSI Phase 3. Based on Phase 3, the frequency of weighing the knockout pot during PSI Phase 4 will be recommended.

Method - A lifting fixture and load cell will be used to weigh the knockout pot without removing the connecting piping. Cold testing will verify the ability to weigh the knockout pot with this method.

Criteria/Data Use - The rate of uranium metal accumulation in the knockout pot will be assessed relative to the knockout pot weight limit for lifting purposes and relative to a lower limit that could be imposed to assure thermal stability.

Expected Range - The knockout pot will weigh approximately $250 \mathrm{~kg}$ empty. The approximate volume of the knockout pot is 1201 . Assuming no more that 601 of material could accumulate in the pot before blinding occurs, weights of material that could accumulate in the pot are as follows.

\begin{tabular}{|l|c|c|c|}
\hline Material & Assumed Density & Weight of 601 & Weight of 60 1 in water \\
\hline Oxide & 2.5 & $150 \mathrm{~kg}$ & $90 \mathrm{~kg}$ \\
\hline Uranium & 19 & $1140 \mathrm{~kg}$ & $1080 \mathrm{~kg}$ \\
\hline
\end{tabular}

Note that there will be a very significant difference in the weight of accumulated oxide and uranium. The maximum weight that the current load cell can handle is $900 \mathrm{~kg}$, so accumulating $60 \mathrm{l}$ of uranium would not be acceptable. Further, limiting the collected mass to $350 \mathrm{~kg}$ has been suggested as a means of assuring thermal stability in the knockout pot. This limit would have no impact if the collected mass is primarily oxide.

Requirements - A procedure, lifting fixture, and load cell will be required for this weighing.

\subsubsection{Sample IXM Inlet and Outlet}

Sequence - Sampling will be done once per shift while the cleaning machine is running during the PSI. The frequency of additional sampling will be determined based on results during the PSI. Samples will also be taken at the CVDF inlet and outlet during bulk water draining of the MCOs selected for monitoring.

Method - Connections for sampling on both the inlet and outlet of the IXMs are included in the design. Samples will be removed and sent to the laboratory for analysis of filtered and ulfiltered total alpha. 
Criteria/Data Use - The data will be used to assess the rate of IXM usage and the potential for allowing disposal of IXMs as non-TRU waste.

Expected Range - Ranges are unknown at this time.

Requirements $-\mathrm{A}$ procedure for the sampling will be required.

\subsubsection{IWTS Effluent Water Clarity Evaluation}

| Sequence - Samples of the IWTS effluent will be evaluated during the PSI.

Method - A sample will be sent to the laboratory and measured for turbidity.

Criteria/Data Use - Readings will provide an indication of the effectiveness of the IWTS filtration. These will be used in conjunction with observations of the clarity of the water in the working area.

Expected Range - The IWTS is expected to provide effluent no greater than 1 NTU.

Requirements - There are no new requirements.

\subsubsection{Radiation Levels in IW'TS}

Sequence - Radiation levels in the IWTS will be measured at the conclusion of the PSI.

Method - Gamma radiation levels will be measured at the IWTS piping, sand filter, knockout pot, and settlers at the conclusion of Phase 4 the PSI.

Criteria/Data Use - These readings will provide early indication of the accumulation of deposits that could lead to unacceptable levels during processing. The measurements will also provide inputs for sludge removal project design.

Expected Range - Radiation levels in the IWTS are unknown at this time.

Requirements - No new requirements 


\subsection{INTERFACES}

Process Validation activities will be planned to minimize data interpretation and process feedback decisions by operators. Operators will provide data to the Data Evaluation Team (discussed in Section 6) and samples to the laboratory. The laboratory will provide results to the Data Evaluation Team. The interpretation of the data and related process feedback will be the responsibility of that team. The following table describes operations interfaces associated with each Process Validation step.

Table 2, Process Validation Interfaces

\begin{tabular}{|c|c|c|c|}
\hline Process Validation Step & Deliverable & To & Number \\
\hline 4.1.1 Visual examination prior to cleaning & Video Image & DET & 35 \\
\hline 4.1.2 Weigh fuel prior to cleaning & Weight & DET & 35 \\
\hline 4.2.1 Measure radiation of effluent during cleaning and decapping & Strip chart & DET & 35 or less \\
\hline 4.2.2 Weigh canister after cleaning & Weight & DET & 35 \\
\hline 4.2.3 Visual examination of fuel after cleaning & Video Image & DET & $\begin{array}{l}\text { Canisters } 35 \\
\text { Assem. } 490 \\
\end{array}$ \\
\hline 4.2.4 Visually inspect canister after dumping & Video Image & DET & 35 \\
\hline 4.2.5 Weigh canister after dumping & Weight & DET & 35 \\
\hline 4.2.7 Visually inspect coarse scrap & Video Image & DET & 3 or more \\
\hline 4.2 .8 Weigh coarse scrap & Weight & DET & 35 \\
\hline 4.2.9 Visually inspect fine scrap & Video Image & DET & 3 or more \\
\hline 4.2.10 Weigh fine scrap & Weight & DET & 70 \\
\hline 4.2.11 Visually inspect fine scrap in cleaning machine screen & Video Image & DET & 12 \\
\hline 4.2.12 Weigh fine scrap in cleaning machine screen & Weight & DET & 12 \\
\hline 4.2.13 Observe gas bubbles from scrap canisters after cleaning & Video record & DET & 3 \\
\hline 4.3.1 Weigh scrap and fuel & Weight & DET & 90 \\
\hline 4.3.2 Weigh coarse and fine scrap & Weight & DET & 12 \\
\hline 4.3.3 Visual examination of loaded fuel and scrap baskets & Video Image & DET & 119 \\
\hline 4.3.4 Observe gas bubbles from loaded baskets & Video record & DET & 10 \\
\hline 4.4.1 Measure centerline temperature of loaded $\mathrm{MCO}$ & Temperature & DET & 1 \\
\hline 4.4.2 Measure radiation levels of loaded MCO & Radiation survey & DET & 3 \\
\hline 4.5.1 Radiation level survey prior to transfer to CVD & Radiation survey & DET & 3 \\
\hline 4.5.2 Measure temperature rise after cask transfer to CVD & Temperature & DET & 3 \\
\hline 4.5.3 Measure pressure rise after cask transfer to CVD & Pressure & DET & 3 \\
\hline 4.5.4 Gas sample after transfer to CVD & Gas sample & Lab & 3 \\
\hline 4.6.1 Corrosion power test before bulk water drain & $\begin{array}{l}\text { Temperature } \\
\text { Helium flow } \\
\text { Hydrogen conc. } \\
\text { Xenon conc. }\end{array}$ & DET & 7 \\
\hline 4.6.2 Neut/gamma cask before/after MCO drain \& cask drain & Radiation survey & DET & 3 \\
\hline 4.6.3 Neut/gamma lines/equip before/during/after MCO drain & Radiation survey & DET & 3 \\
\hline 4.7.1 Gas generation during CVD & $\begin{array}{l}\text { Helium flow } \\
\text { Hydrogen conc. } \\
\text { Xenon conc. } \\
\text { Nitrogen conc. }\end{array}$ & DET & 7 to 24 \\
\hline 4.7.2 Neutron and gamma survey before shipment from CVD & Radiation survey & DET & 4 \\
\hline 4.8.1 Neutron and gamma survey at CSB receipt & Radiation survey & DET & 4 \\
\hline 4.9.1 Weigh knockout pot & Weight & DET & TBD \\
\hline 4.9.2 Sample inlet and outlet of IXM & Water sample & $\mathrm{Lab}$ & TBD \\
\hline 4.9.3 Radiation levels in IWTS & Radiation survey & DET & 9 \\
\hline 4.9.4 IWTS effluent water clarity evaluation & Water Sample & $\mathrm{Lab}$ & 3 \\
\hline
\end{tabular}




\subsection{DATA EVALUATION TEAM}

Interpretations of data and comparisons of data to predictions based on modeling will be done by a Data Evaluation Team.

A team of approximately five individuals representing operations and engineering will be identified as a Data Evaluation Team. They will assess fuel cleaning effectiveness, fuel damage, and particulate estimates to establish visual standards for operations, interpret results to confirm or adjust equipment performance, and confirm acceptable MCO behavior. These assessments will be used to perform trending analysis to estimate the total number of MCOs required and determine changes or additions to Process Validation activities. The team must possess familiarity with the SNF safety basis, characterization data, basin operations, and process engineering. 


\subsection{IMPLEMENTATION OF PROCESS VALIDATION}

Some of the steps in Process Validation occur during the PSI, prior to Operational Readiness Review (ORR). Others occur after startup. After startup, validation activities occur in parallel with other operational activities. In those cases, special procedures and MCO travelers will be required for those MCOs requiring validation steps. Some validation steps are done on initial MCOs and other steps are done on MCOs selected for specific characteristics. The Process Engineer will be responsible to identify what validation steps apply to selected MCOs. Figure 1 is intended to show the relationship of Process Validation to other activities.

\subsection{Validation Procedures}

Process Validation requires additional steps during operations for selected MCOs. The number of additional steps is not the same for all MCOs addressed by Process Validation. The Operational Procedures will need to be supplemented with procedures that address the additional steps. In addition, methods need to be in place to clearly identify which MCOs require which additional steps.

\subsection{Validation Traveler}

Additional data will be recorded for those MCOs subject to Process Validation. The traveler will need to be supplemented to include the information required for Process Validation.

\subsection{Validation Report(s)}

Process Engineering will prepare reports that provide data and conclusions from all Process Validation steps. 
Figure 1, Process Validation Tasks

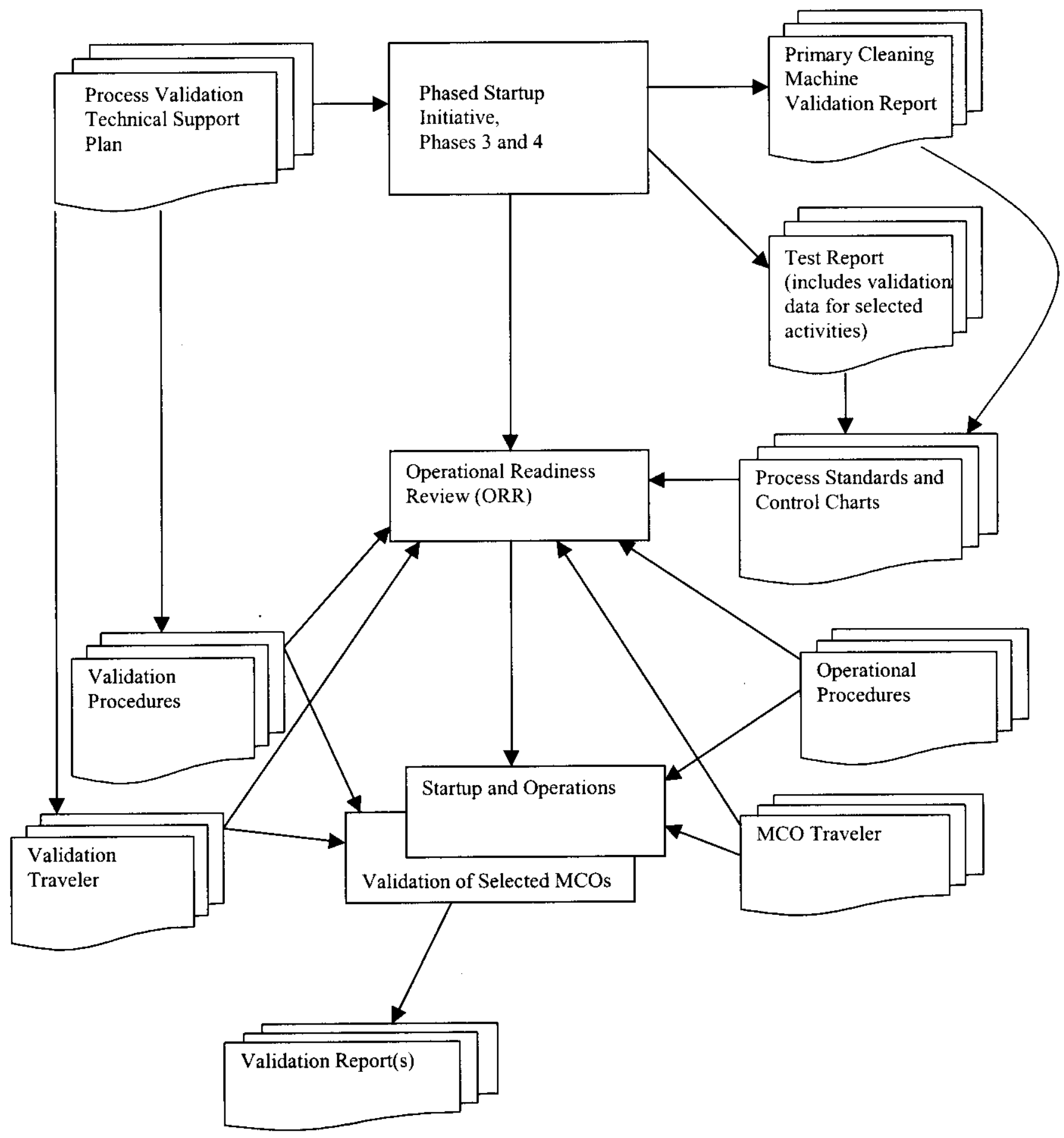




\subsection{REFERENCES}

Duncan, D. R., and R. A. Sexton, 1998, Submerged Weight of Scrap Baskets Issue Closure Package, HNF-3058, Rev. 0, DE\&S Hanford, Richland, Washington

Lorenz, B. D., 1999, Multi-Canister Overpack Topical Report, HNF-SD-SNF-SARR005, Rev. 1, Fluor Daniel Hanford, Richland, Washington

Pajunen, A. L., and M. J. Packer, 1999, Fuel Removal Campaign Plan, HNF-3635, Rev. C, DE\&S Hanford, Richland, WA

Pajunen, A. L., A. L. Pitner, and D. W. Smith, 2000, Phased Start Up Initiative Phases 3 and 4 Test Plan and Test Specifications (OCRWM), HNF-4898, Rev. 0, Fluor Hanford, Richland, WA

Pajunen, A. L., 1999, Uranium Oxidation Rate Summary for the Spent Nuclear Fuel Project, HNF-4165, Rev. 0, DE\&S Hanford, Richland, Washington

Sexton, R. A., 1998, MCO Monitoring Activity Description, HNF-3312, Rev. 1, DE\&S Hanford, Richland, Washington

Stegen, G. E., and R. A. Sexton, 2000, Fuel Retrieval System Fuel Cleanliness Process Validation Procedure (OCRWM), SNF-3896, Rev. 1, Fluor Hanford, Richland, Washington 


\section{DISTRIBUTION SHEET}

\begin{tabular}{|c|c|c|c|c|c|}
\hline \multirow{2}{*}{$\begin{array}{l}\text { To } \\
\text { Distribution }\end{array}$} & \multirow{2}{*}{\multicolumn{3}{|c|}{$\begin{array}{l}\text { From } \\
\text { Process Engineering }\end{array}$}} & \multicolumn{2}{|l|}{ Page 1 of 1} \\
\hline & & & & \multicolumn{2}{|l|}{ Date $4 / 27 / 00$} \\
\hline \multicolumn{4}{|c|}{ Project Title/Work Order } & \multicolumn{2}{|l|}{ EDT No. N/A } \\
\hline \multicolumn{4}{|c|}{ Spent Nuclear Fuel Process Validation Technical Support Plan, SNF 4909, Rev. 1} & \multicolumn{2}{|c|}{ ECN No. 660118} \\
\hline & MSIN & $\begin{array}{c}\text { Text } \\
\text { With All } \\
\text { Attach. }\end{array}$ & Text Only & $\begin{array}{l}\text { Attach./ } \\
\text { Appendix } \\
\text { Only }\end{array}$ & $\begin{array}{c}\text { EDT/ECN } \\
\text { Only }\end{array}$ \\
\hline
\end{tabular}

Spent Nuclear Fuel Project

W. C. Alaconis

G. D. Bazinet

M. R. Butcher

W. T. Covington

D. R. Duncan

R. L. Garrett

L. H. Goldmann

J. R. Gregory

J. J. Irwin

M. J. Langevin

J. D. Mathews

S. S. Moss

A. L. Pajunen

A. L. Pitner

R. W. Rasmussen

T. J. Ruane

O. M. Serrano

R. A. Sexton

J. L. Shelor

J. P. Sloughter

G. E. Stegen

J. A. Swenson

SNF Project Files

$\begin{array}{ll}\text { X3-79 } & \text { X } \\ \text { S8-06 } & \text { X } \\ \text { S0-10 } & \text { X } \\ \text { S0-10 } & \text { X } \\ \text { R3-86 } & \text { X } \\ \text { R3-26 } & \text { X } \\ \text { R3-86 } & \text { X } \\ \text { X3-78 } & \text { X } \\ \text { R3-86 } & \text { X } \\ \text { X4-01 } & \text { X } \\ \text { X3-65 } & \text { X } \\ \text { R3-11 } & \text { X } \\ \text { R3-86 } & \text { X } \\ \text { R3-86 } & \text { X } \\ \text { X3-85 } & \text { X } \\ \text { X3-61 } & \text { X } \\ \text { S2-44 } & \text { X } \\ \text { R3-86 } & \text { X } \\ \text { X4-04 } & \text { X } \\ \text { K9-46 } & \text { X } \\ \text { X4-01 } & \text { X } \\ \text { R3-1 1 } & \text { X } \\ \text { R3-11 } & \text { X }\end{array}$

